\title{
ECONOMIC IMPACT OF MICROFINANCE IN NEPAL: A CASE STUDY OF THE MANAMAIJU VILLAGE DEVELOPMENT COMMITTEE, KATHMANDU
}

\author{
Dipak Bahadur Adhikari* and Jayanti Shrestha**
}

\begin{abstract}
The concept of micro-credit was developed to mobilize small savings of poor people to create deposit, which may be accessible to unreachable and un-bankable poor, especially women. The study has highlighted that microfinance is an effective tool for bringing positive impact on the economic status of the respondents along with their family members. It has helped to generate extra income for their family and their own use. The extra income allows the respondents family to buy nutritious food, access to modern health care services and they can afford to send their children to the school.
\end{abstract}

Key words: microfinance, loanees, non-loanees, Manamaiju VDC, Women Support Cooperative (WSC)

\section{INTRODUCTION}

Microfinance plays an important role in fighting the multi-dimensional aspects of poverty. Microfinance is an innovation for the developing countries. It provides self-employment opportunity for poor people who are unemployed, entrepreneurs and farmers who are not bankable because of the lack of collateral, very low level of income. It has successfully enabled poor people to start their own business generating income and often beginning to build up wealth. It has the capacity to enhance the socio-economic development of the vulnerable and marginalized people, especially women.

Microfinance is a simple but effective credit tool that enables the most poor to pull themselves out of poverty. It involves advancing small loans to the working poor. These loans are usually less than $\$ 200$ and made by local organizations called microfinance institutions (MFIs). Microfinance helps the working poor to establish or expand small businesses that generate additional income for the family use. This extra income allows a poor family to buy food, access healthcare, educate their children, put aside savings and lay the foundation for a better future. Microfinance is one of the best alternatives to generate self-employment. It provides services to the communities who have no collateral to offer against the loans they take but have indigenous skills and strong

* Mr. Adhikari is Assistant Lecturer of Economics at Patan Multiple Campus, Tribhuvan University, Nepal ${ }^{* *}$ Mrs. Shrestha is Lecturer of Economics at Padma Kanya Multiple Campus, Tribhuvan University, Nepal 
desire to undertake economic activities for self employment and income generation (Shrestha, 2009).

Microfinance increases household income, which leads to food security, the building of assets, and an increased likelihood of educating children. Microfinance is also a means for self-empowerment. It enables the poor to make changes when they increase income, become business owners and reduce their vulnerability.

"Microcredit, or microfinance, is banking the un-bankable, bringing credit, savings and other essential financial services within the reach of millions of people who are too poor to be served by regular banks, in most cases because they are unable to offer sufficient collateral. In general, banks are for people with money, not for people without"(Maanen, 2004). Microfinance has emerged as an effective poverty alleviation tool because it is based on the fundamental principle that human beings are motivated to do whatever it takes to make themselves as well as possible. (www.grameen-info. org/bank/).

People in the society are not equally capable and skillful. Therefore, an access, opportunity, right to control over resources should provide these people according to their capabilities. Control over loan, loan related activities, and expenditure of earnings are three kinds of benefits that must be equally shared among male and female members in the family. The question arises whether loanees share the benefits or not.

Simojoki (2003) analyzed the impact of micro-finance and opportunities to female microentrepreneurs in the informal sector in Nairobi, Kenya with the objective of clarifying how micro-entrepreneurs have benefited from credit and financial services. The study showed the inter-relationship among social and economic empowerment. Income generating activities were necessary for women. Control over credit and business has shown as an important indicator of empowerment. Related activities play an important role for the success of any microfinance program and their ability to contribute to women empowerment. Microfinance with neo-liberal priorities could help them for self-confidence and substantial tools to improve their lives. The most important part in effective microfinance is women's participation and the strengthening of their sense of responsibility. The author suggests that an explicit policy of empowerment and related activities need microfinance programs for women empowerment. The government should promote various opportunities and fight against the exploitative features of the informal sector.

ADB (2001) shows the potential demand of microfinance services in the region for poverty reduction. This report has tried to present the review of its microfinance (MF) during last decade. The three background papers (Leading Issues in Microfinance; Supervision and Regulation of Microfinance Institutions; The Role of Central Banks in 
Microfinance) were prepared for the workshop summing up in different but interrelated aspects of MF in the development process. The paper highlights the importance of MF services that it could enable the poor gradually to build up their assets, develop their enterprises, enhance their earning capacity, smooth on consumption and manage their risks better. The paper has focused on the policy environment; the improvement of financial infrastructure; overcoming the inadequate institutional capacity of MFIs; the support of pro-poor innovative programs and development of financial technology areas in the draft strategy.

Charitonenko and Silva (2002) has analyzed the progress toward commercialization of microfinance industry in Sri Lanka in their report on Commercialization of microfinance. They have emphasized to explore the remaining challenges and the implications, prospects, and positive approaches to the commercialization of microfinance. The researchers pointed out the growing realization that commercialization allowed MFIs greater opportunities to fulfill their social objectives of providing the poor with increased access to a whole new array of demand-driven microfinance products and services. The report considered commercialization of microfinance at micro as well as macro levels. The microfinance industry in Sri Lanka was at an early stage of commercialization. Microcredit market dissemination appeared high at about 80 percent. Based on household data and the current savings average outstanding microloan amount of $\$ 193$ and their microenterprises estimated to be around $\$ 254.9$ million with 2.3 million microloans. At the end of 2000, MFIs had approximately \$202.3 million outstanding in 1.65 million microloans. In Sri Lanka, cooperatives are the dominant microfinance providers and the movement continues to influence how NGOs deliver microfinance. While many cooperatives were sustainable and their performance varies, more than one third of the supply was provided through government programs, which can be considered supply-led and not commercially viable.

Fernando (2006) explained that the MFIs charging high prices to cover costs for any business was an essential practice. His study reports that the highest interest rates charged by most of the MFIs in the region ranged from 30 percent to 70 percent a year on a reducing balance basis. The question arises why microcredit rates are so high? Because of these four key factors: the cost of funds; the MFI's operating expenses; loan losses; and profits needed to expand their capital base and fund expected future growth, determined the rates. Imposing ceiling on microcredit interest rates was not the permanent solution of the problem, although lower microcredit interest rates will help to increase the availability of affordable finance for poor household. The study has shown evidence in the Asia Pacific region, which strongly supports the view that liberal interest rate policies fuel the growth of the microfinance industry. More than 50 million poor people have access to microcredit from formal and semi-formal institutions in the region. The study has explained in detail about the general impact of ceilings on microcredit interest rates such as, short term, medium term and long- 
term effects on supply as well as in demand side. In those countries where interest rate ceilings have been a major characteristic of the market, growth of outreach had been disappointingly low. In most of the developing economy, the best available investment opportunities for a majority of poor households involve those with moderate returns. Household in this category cannot be expected to have the same ability to service loan taken at high interest as those who realize high returns on their investments. Similarly, poor households need credit to meet expenditure on health, education and many lifecycle events. Policy makers can oppose requests to impose rate ceiling that will slow down the growth of the MFI industry and result in reducing the supply of microcredit and other financial services, harming rather than helping poor and low income households.

INAFI SAP-Nepal (2004) conducted a thematic research study on the "Impact of Microfinance Services on Poverty Reduction in Nepal". The main objective of the study was to find out the overall impact of microfinance services on poverty reduction in the country. The study focused on (i) outreach of microfinance, (ii) access, use and contribution of microfinance, (iii) micro-enterprise development, (iv) managing risks and vulnerabilities by clients, (v) empowerment of women, and (vi) poverty reduction.

Both primary and secondary data were used for the analysis. In the study, both 'before and after' and 'with and without' approaches were used. The major finding of the study was the positive impact of microfinance on poverty reduction. Microfinance enabled the poor to enhance their access to financing for income growth and welfare improvement through micro-enterprise development and increased ability to address vulnerability and economic empowerment; Microcredit was used for production $(66 \%)$ and the remaining for consumption. Microfinance contributed to reduce poverty in client households. Respondents increased their incomes by 56 percent after participation in the microfinance programs. Beneficiaries have increased slightly more financial, physical and human capital than non-clients; Microcredit has served to lessen their dependency on moneylenders, reducing the average interest rate burden especially for the poor; Microcredit has promoted micro-enterprise activities, which in turn have increased wage and self-employment opportunities for the beneficiaries and the community people. There is great need to expand the MFIs in high hills and mountains, where the majority of poor lives.

Bashyal (2005) studied and evaluated the impact of microfinance program on poverty reduction in her Ph.D. dissertation entitled "Impact of Microcredit Programs on Poverty Alleviation in Nepal: A Case study of Rupandehi District". She gave more emphasis on her study that women will not be empowered until and unless they get benefited both qualitatively and quantitatively with the promotion of gender equality. Overall objectives of the study were to evaluate the socio-economic impact and implications of microfinance on poverty alleviation through empowering women, 
and also evaluate the impact on natural resource management. The Nirdhan Utthan Bank Limited (NUBL) situated in Rupendehi district, Bhairahawa, was selected for the purpose of case study. This study assumed that microfinance can reduce both income and human poverty over a period of time. If women are empowered economically and socially, they can increase their skill and confidence level to think of themselves as equal to men.

Shrestha (2010) analyzed the Microfinance and social Mobilization in the context of ADBL (Agricultural Development Bank, Nepal) in promoting SFCLs (Small Farmers Cooperative Limited) in his book entitled "Financial Performance of Small Farmers Cooperative Limited in Nepal." Considering the positive outcome of SFDP in terms of targeting the poor for their overall well-being, expansion of the program was highly demanded in rural Nepal to deliver services to the poor and disadvantaged groups. Social mobilization is also equally required in order to improve and maintain the better financial performances of SFCLs.

Microfinance and its contribution in the economy are significant. This sector contributes to reduce poverty, unemployment and inequality. This sector is self employment generation and tries to raise leaving standard of people. Very few researches have been carried out in the case of developing countries like Nepal. But some effort has been made to find out the problem and these efforts are not sufficient. So a fresh and new research is significant.

\section{OBJECTIVE OF THE STUDY}

The main objective of the study is to evaluate the Economic impact of microfinance in Nepal with special reference to Manamaiju VDC.

\section{RESEARCH METHODOLOGY}

A number of steps were followed to accomplish the present study.

\subsection{Research Design}

This paper aim to analyze the economic impact of the respondents with the help of some determinant variables: loanee's income, household income, household consumption, Savings, household assets, improvement in living standards, accessibility to credit, initiation of income generating activities.

In social science research, field work is the central and important method for collecting the primary information. Secondary information also plays an important role while analyzing and giving inference of some empirical knowledge (Adhikari, 2011). The study is based on both primary and secondary data. Both qualitative and quantitative approaches were used for data analysis. The study has analyzed and compared the 
various indicators of economic status between loanees and non-loanees. As far the primary data is concerned, structured questionnaire was used to collect data.

\subsection{Sampling Design}

The present study is an economic impact study of microfinance program of Women Support Cooperative Limited (WSC) in Manamaiju VDC of Kathmandu district. The study has been conducted to examine and compare the conditions of respondents (loanees and non-loanees) of the microfinance program before and after being a member of WSC. The word loanees stand for loan users and non-loanees stand for savers only. The study has also examined the respondents' before and after conditions of the health and education level of their children.

\subsection{Size of Sample}

There are 21 centers (Women's Support micro-credit centers) within the Manamaiju VDC. Among the 541 members in the 21 centers, 348 were loanees and 193 were nonloanees. Sample comprises all 21 centers of the Manamaiju VDC. A 33 percent of the total population has been taken as a sample. The sample size was 186 which included both 121 loanees and 65 non-loanees. The information was taken within three months period from January 1, 2012 to April 1, 2012. SPSS software package has been used to calculate Chi-square test, t-test.

\section{EMPIRICAL RESULT AND DISCUSSION}

The analysis of data and discussion on the outcomes are made under different subheadings.

\subsection{Economic Status of the Respondents}

Under the economic status, respondent's household income, land-holding sizes, type of occupation are the main variables considered for the study.

\subsubsection{Average Land Holding Size}

Table 1 show that loanees and their family have more landholding than that of nonloanees.

Table 1: Average Land Holding Size (Loanees and Non-loanees)

\begin{tabular}{lcc}
\hline Type of Land(in Ropani) & Loanees & Non-loanees \\
\hline Khet & 3.6 & 2.96 \\
Pakho & 2.9 & 2.00 \\
Total & 6.5 & 4.96 \\
\hline
\end{tabular}

Source: Authors' calculation from field survey data, 2012. 
Loanees and their family members (household) own 3.6 ropani of khet and 2.9 ropani of pakho lands. On the other hand, non-loanees and their family hold only 2.96 ropani of khet and 2.0 ropani of pakho lands. The table indicates that the loanees were better off than the non-loanees. However, these lands situated in hilly areas were the property of joint-family. After migrating to the valley, there remains very little opportunity to use them.

\subsubsection{Major Sources of Loanees' and Non-loanees' Household Income}

Table 2 reveals that respondents were engaged in more than one occupation for earning their livelihood. Main occupation of local respondents of the surveyed area was agriculture (including food grain and vegetable farming).

Table 2: Distribution of Loanees and Non-loanees by Major Sources of Household Income Before and After Taking Membership

\begin{tabular}{lcccccc}
\hline Sources of Income & \multicolumn{3}{c}{ Loanees } & \multicolumn{3}{c}{ Non-Loanees } \\
\cline { 2 - 7 } & Before & After & $\begin{array}{c}\text { Percentage } \\
\text { Change }\end{array}$ & Before & After & $\begin{array}{c}\text { Percentage } \\
\text { Change }\end{array}$ \\
\hline Agriculture Farming & 30 & 34 & 13.33 & 16 & 15 & -6.25 \\
Cottage Industry & $(24.79)$ & $(28.10)$ & & $(24.62)$ & $(23.08)$ & \\
& 14 & 21 & 50.00 & 4 & 6 & 50.00 \\
Business/ Trade & $(11.57)$ & $(17.36)$ & & $(6.15)$ & $(9.23)$ & \\
& 65 & 74 & 13.85 & 18 & 21 & 16.67 \\
Wage Labor & $(53.72)$ & $(61.16)$ & & $(27.69)$ & $(32.31)$ & \\
& 16 & 19 & 18.75 & 16 & 16 & 0.00 \\
Remittance & $(13.22)$ & $(15.70)$ & & $(24.62)$ & $(24.62)$ & \\
Service & 2 & 5 & 150.00 & $(6.15)$ & $(6.15)$ & 0.00 \\
& $(1.65)$ & $(4.13)$ & & 33 & 32 & -3.03 \\
Others/ Specify & 37 & 41 & 10.81 & $(50.77)$ & $(49.2)$ & \\
Total, n=121 & $(30.58)$ & $(33.88)$ & & 11 & 11 & 0.00 \\
\hline
\end{tabular}

Source: Authors' calculation from field survey data, 2012.

Note: Figure shown in parenthesis represents the percentage. ${ }^{*}$ Others/ Specify includes Rent and Pension.

The migrant respondents were usually engaged in trade/business, wage labor, and service. By observing Table 2, it is seen that 14 loanees were engaged in cottage industries before they began participating in the MFI. The number of loanees increased to 21 after they joined WSC. This means that the cottage industry as an occupation of 
the loanees, increased by 50 percent. It is noticed that there was a remarkable increase in respondents' enterprise activities.

This is interesting to note that remittance-earners were observed to be the husbands of loanees. Those (remittance receiving) loanees had joined the institution not primarily to undertake any ventures but to get social companionship. It was also observed that these types of loanees used to buy luxuries with the loans and made paybacks with the remittance money which was sent by their husbands regularly.

The non-loanees were not credit-taking group; rather they were depositor/savers. So their sources of income were independent of WSC. Hence, a comparison of changes in the sources of incomes between loanees and non-loanees would make an interesting analysis. The sources of household income for loanees before they joined the WSC were 180, which became 215 later on (an increment of 19.44 percent). Similarly, with the non-loanees there were 102 sources, which became 105 during the period (an increment of mere 2.94 percent).

\subsubsection{Sources of Loan Repayment}

Table 3 reveals the sources of loan payment of the user of fund. The loanees business was running in profit.

Table 3: Distribution of Loanees by Source of Loan Repayment

\begin{tabular}{lcc}
\hline Sources of loan repayment & No. of Loanees & Percent \\
\hline Money earned from same business & 102 & 84.30 \\
Other household income & 15 & 12.40 \\
Borrowing from other institution & 1 & 0.82 \\
Relatives/friends & 3 & 2.48 \\
Total & 121 & 100 \\
\hline
\end{tabular}

Source: Authors' calculation from field survey data, 2012

They could repay their bi-weekly loan installment from their own business. Majority of loanees ( 84.30 percent) have been paying their installments from the same business whereas only 12.40 percent were using household income for repayment purpose. Table 3 reflects their level of independency and increased positive attitude towards their business. Some loanee's repayment was made from relatives and/or friends.

\subsubsection{Purpose of Borrowing}

Table 4 reveals on the purpose of borrowing from WSC. Microfinance service in Manamaiju VDC is becoming very popular day by day. 
Table 4: Distribution of Respondents by Purpose of Borrowing

\begin{tabular}{lcccc}
\hline Purpose of taking loan & $1^{\text {st }}$ loan & Percentage & 2nd Loan & Percentage \\
\hline Shop/Business & 69 & 57.02 & 58 & 61.70 \\
Poultry /Duck Farming & 15 & 12.40 & 12 & 12.77 \\
Manufacturing & 10 & 8.26 & 7 & 7.45 \\
Tailoring & 7 & 5.79 & 5 & 5.32 \\
Agriculture/Vegetable Farming & 11 & 9.09 & 6 & 6.38 \\
Buffalo /Cow for milk raising & 4 & 3.31 & 5 & 5.32 \\
Consumption purposes & 4 & 3.31 & 1 & 1.06 \\
Wine & 1 & 0.83 & 0 & 0.00 \\
Total & 121 & 100.00 & 94 & 100.00 \\
\hline
\end{tabular}

Source: Authors' calculation from field survey data, 2012.

WSC has been providing loan for undertaking income-generating activities like trade/ business, poultry farming, manufacturing, agriculture farming, and livestock farming. Some amount of the loan is used for purchasing assets, household consumption, foreign employment, and repayment of loans. Out of 121 loanees only 4 people had taken loan for consumption purpose. The rest 117 took loans for productive activities. Amount demanded for the purpose of first loan was shop/business, which stands higher (57.02 percent) followed by poultry (duck) farming (12.40 percent) whereas second loan was demanded by 61.70 percent of loanees for shop/business and poultry (duck) farming by 12.77 percent. This proves that these micro credits were not only used productively, but they themselves induce taking further credits. This means the loanees entrepreneurial capacity and the intention to grow has been positive. One loanee was seen indulging himself in wine making activity, which is not a legal activity. No loan has been given in this category.

\subsection{Economic Impact Assessment of Microfinance Program}

Economic impact assessment refers to the effects of MFP on respondent's economic aspects. The program helps not only the loanees but also their family members and the community. The impact assessment is made here on different headings.

\subsubsection{Average Household Expenditure of Loanee's by Expenditure Item}

There has been a considerable increase in the household expenditure of WSC members (loanees) after participation in the micro-credit program. The expenditure a propensity of the households is highlighted by means of Table 5 . 
Table 5: Average Household Expenditure of Loanees

\begin{tabular}{lccccc}
\hline \multirow{2}{*}{ Items } & \multicolumn{2}{c}{ Before } & \multicolumn{2}{c}{ After } & Changed \\
\cline { 2 - 5 } & Rs. & Percent & Rs. & Percent & Percent \\
\hline Food Expenses & 87,921 & 71.73 & 119,636 & 68.51 & 36.07 \\
Clothing & 5,781 & 4.72 & 9,339 & 5.35 & 61.54 \\
Pure Drinking Water & 407 & 0.33 & 997 & 0.57 & 144.82 \\
Child Education & 22,255 & 18.16 & 32,555 & 18.64 & 46.28 \\
Social Expenses & 2,966 & 2.42 & 5,169 & 2.96 & 74.28 \\
Health Treatment & 3,236 & 2.64 & 6,939 & 3.97 & 114.46 \\
Total (n=121) & 122,567 & 100.00 & 174,636 & 100.00 & 42.48 \\
\hline
\end{tabular}

Source: Authors' calculation from field survey data, 2012.

The average household expenses on food had increased after the people joined WSC (from Rs. 87,921 to Rs. 119,636) reflecting an increase by 36.07 percent. After participating in WSC, the changed percent of loanee's expenses in health treatment of own and their family members had reached up to 114.46 percent. Similarly, the clothing expenses changed by 61.54 percent.

Table 6 compares the same household expenses in another statistical format, the paired t-test.

Table 6: Difference in Average Expenditure by Item

\begin{tabular}{lccc}
\hline Method: Paired t-test & Statistic $=\left(X_{\text {before }}\right)-\left(X_{\text {after }}\right)$ & & \\
\hline Items & t-statistic & Df & p-value \\
\hline Food Expenses & -5.73 & 120 & $<.001$ \\
Clothing & -12.33 & 118 & $<.001$ \\
Pure Drinking Water & -1.825 & 13 & $>0.05$ \\
Child Education & -3.072 & 79 & $<0.01$ \\
Social Expenses & -6.354 & 56 & $<.001$ \\
Health Treatment & -2.74 & 84 & $<0.01$ \\
Total & -7.507 & 120 & $<.001$ \\
\hline
\end{tabular}

Note: $\mathrm{df}=$ degrees of freedom ; Level of significance $=5 \%$

Source: Authors' calculation from field survey data, 2012.

With the participation at WSC, the minimum income level increased by 461 percent. The median value increased by 48.99 percent whereas the maximum expenditure 
rose only by 10.13 percent. As a result of increased economic standard, the amount of annual expenditure on food and non-food items has increased.

At $5 \%$ level of significance, Table 6 shows that there is a significant difference in average expenses between before and after joining the WSC by households for all items food, clothing, child education, social activity and health treatment (except pure drinking water). Similarly, there is a significant difference in average expenses between before and after joining the WSC by household for overall expenses.

\subsubsection{The Utilization of Profit Earned by Loanees}

Activities undertaken with micro-credit provided by the WSC have been contributing to increase the household income of the loanees. The credit amounts have been invested in various sectors and these investments have proved to be profitable ventures. Table 7 shows the loanees' reinvestment of additional income generated from their MFI ventures.

An enormous 64.46 percent of loanees had given first preference to reinvesting in their own business. When asked to rank their second preferences 42.15 percent answered that they would spend it in household expenses. The third preference was given to children's education (9.09 percent in first rank and 20.66 percent in second rank preferences).

Table 7: Distribution of Loanees by the Purpose of Utilization of Income (Profit)

\begin{tabular}{lcccccc}
\hline Utilization of Income & $\begin{array}{c}\text { 1st } \\
\text { Rank }\end{array}$ & percent & $\begin{array}{c}\text { 2nd } \\
\text { Rank }\end{array}$ & percent & $\begin{array}{c}\text { 3rd } \\
\text { Rank }\end{array}$ & percent \\
\hline $\begin{array}{l}\text { Reinvestment in present } \\
\text { business }\end{array}$ & 78 & 64.46 & 13 & 10.74 & 12 & 9.92 \\
Daily household needs & 10 & 8.26 & 51 & 42.15 & 22 & 18.18 \\
Children's education & 11 & 9.09 & 25 & 20.66 & 47 & 38.84 \\
Gold and Silver & 1 & 0.83 & 3 & 2.48 & 7 & 5.79 \\
Buying Land & 0 & 0.00 & 1 & 0.83 & 0 & 0.00 \\
Health care & 1 & 0.83 & 1 & 0.83 & 6 & 4.96 \\
Savings & 12 & 9.92 & 15 & 12.40 & 16 & 13.22 \\
\hline
\end{tabular}

Source: Authors' calculation from field survey data, 2012.

Table 7 shows that reinvestment in business and savings accounted together for 74.38 percent of use of profits. Loanees were independent to use their profit amount according to their wish and preferences. Similarly, they were very conscious about expanding their business. Table 8 offers the Chi-square test results on the purpose of loan utilization. 
Table 8: Distribution of Loanees by the Purpose of Utilization of Income

\begin{tabular}{lccc}
\hline Utilization of Income & Chi-square & $\mathrm{df}$ & $\mathrm{p}$-value \\
\hline Reinvestment in present & 83.32 & 2 & $<0.01$ \\
business & 32.12 & 2 & $<0.01$ \\
Daily household needs & 23.807 & 2 & $<0.01$ \\
Children's education & 8 & 3 & $<0.05$ \\
Gold and Silver & 6.25 & 2 & $<0.05$ \\
Health care & 0.605 & 2 & $>0.10$ \\
Savings &
\end{tabular}

Source: Authors' calculation from field survey data, 2012.

Since p-value $(<0.05)$ of Chi-square of all type of utilization of income is less than 5 percent level of significance except for saving, the null hypothesis that all three rank of each type of utilization of income has equal proportion is rejected. Thus, it is concluded as follows: Reinvestment in present business has the highest frequency for first rank and frequencies decrease for second rank and third rank accordingly; Daily household needs, has the highest frequency for second rank and frequencies decrease for third rank and second rank accordingly; Children's education has the highest frequency for third rank and frequencies decrease for second rank and first rank accordingly.

However, saving has an insignificant p-value. It means that loanees have not given different frequencies for their ranking as first, second and third.

\subsubsection{Current Savings Status of Loanees and Non-Loanees}

Table 9 indicates the savings trends of respondents (loanees and non-loanees), which they deposited in the center meeting (group meeting) of WSC. The total average saving of loanees has recorded fewer amounts compared to that of non-loanees. Similarly, loanees' minimum as well as maximum savings amount is also shown lesser with comparison to non-loanees. It exhibits that non-loanees were more capable to save, which means loanees were poorer than non-loanees. Some of the descriptive statistics on saving of the loanees and non-loanees in the surveyed area is shown in Table 9.

Table 9: Distribution of Loanees and Non-Loanees by Current Saving

\begin{tabular}{llcc}
\hline Yearly Savings: & Descriptions & Loanees & Non-Loanees \\
\hline & Mean Saving (Rs.) & $8,633.30$ & $11,121.62$ \\
& Median & $7,938.00$ & $8,620.00$ \\
Standard Deviation & $4,569.49$ & 7342.804 \\
& Minimum Saving & $1,671.00$ & $2,791.00$ \\
& Maximum Saving & $36,779.00$ & $39,431.00$ \\
\hline
\end{tabular}

Source: Authors' calculation from field survey data, 2012. 
The figures in Table 9 show that average saving of non-loanees (NRs 11,121) is higher than that of loanees $(8,633.30)$. That can be anticipated as the household with higher saving tend to borrow low. That means, if a household has sufficient saving to mitigate the risk it could face, there is less likely the chance that household will be borrowing from the MFI. The median figure, however, shows less variation of saving between loanees and non-loanees. This indicates that average figure could have inflated due to presence of outlier households. That is, few households have excessively higher amount of saving. This result also reflected on standard deviation.

\section{CONCLUSION}

Level of income was one of the indicators used to test the change in living standard of loanees. It was reported that 98.00 percent of the loanees said that they are earning profits. On an average, each of the loanees (except two) has earned NRs. 98,941 as a profit. However, 79.33 percent of the loanees have earned profits up to NRs. 1, 50,000. It reveals that the loan became highly effective for the loanees. It is an indicator of the fact that the program has highly positive impact on the loanees' economic status. Compared to the average profit (NRs. 98,941) the ratio of profitability of loan was 416.56 percent. This shows that the micro credit program has been very successful in the survey area.

Thus to alleviate the poverty in the country, microfinance became an effective tool. In this context, the study area (Manamaiju VDC) was selected where WSC has implemented the first microcredit program to uplift the socio-economic status of the women of that area. Consequently, the following findings are arrived at from the study:

The economic status of loanees has improved consequently than when they started small business with loan in the earlier days. Moreover, it was found that their socioeconomic status was higher than that of non-loanees. From all these we can conclude that microcredit is an effective tool for raising the socio-economic status of the poor people, particularly the women.

As revealed by the study, the loanees were demanding that the loan size should be increased; effective means should be developed to identify the poor and target them for loan, training, and regular follow up should be conducted. The outreach of the institution should be enhanced. Modern technology should be applied to increase the efficiency and to provide service in remote areas. The study reveals that economic status of women has risen due to income generating activities and they were socially empowered due to group solidarity created by microfinance program. They can raise voice against gender discrimination. 


\section{References}

Adhikari, D. B. (2011). Income generation in informal sector: A case study of the street vendors of Kathmandu metropolitan city. Economic Journal of Development Issues 13-14(1-2)

Asian Development Bank (2001). ADB Annual Report 2001, retrieved March 10, 2012 from www.adb.org/documents/adb-annual-report-2001

Bashyal, R. (2005). Impact of microcredit programs on poverty alleviation in Nepal: A case study of Rupandehi district. (A Ph.D. dissertation submitted to Tribhuvan University), Kathmandu

Charitonenko, S. \& Rahman, S. M. (2002). Commercialization of micro finance: Bangladesh. Manila: ADB

Fernando, N. (2006). Understanding and dealing with high interest rates on microcredit. Manila: Asian Development Bank

INAFI SAP-Nepal (2004). Microfinance services in insurgency and conflict: A case study of Nepal, INAFI, SAP-Nepal. Kathmandu Nepal Rastra Bank Economic Report

Maanen, G. V. (2004). Microcredit: Sound business or development instrument, oikocredit, retrieved Jun15, 2012 from http://www.microfinanceinfo.com/the-definitionof-microfinance

Shrestha, P. (2010). Financial performance of small farmers' cooperative limited in Nepal. Kathmandu: Oriental Publication.

Simojoki, H. (2003). Empowering credit-more than just money: The socio-economic impact of micro-finance on women in Nairobi, Kenya, University of Jyväskylä, Department of Social Sciences and Philosophy, Kenya, retrieved August 10, 2012 from www.acrobatplanet.com/non-fictions-ebook/pdf-ebook-empowering-creditmore-just-money.html

Shrestha, S. M. (2009). State of microfinance in Nepal. As part of the project on state of microfinance in SAARC countries. Institute of Microfinance (InM). Retrieved March 11, 2012 from http://www.rmdcnepal.com/form/state_of_microfinance_ in_nepal_2011.pdf 